\title{
O tirano e o látego: um estudo sobre a violência de Estado em dois romances de Dyonélio Machado
}

\author{
Marcus Rogério Salgado
}

\footnotetext{
RESUMO: O presente artigo é um estudo sobre as representações da violência de Estado figuradas nos romances Desolação e Passos perdidos, do escritor sul rio-grandense Dyonélio Machado. Para tanto, faz-se necessário compreender a formação da consciência política do personagem Manivela nas duas narrativas, cujas ações ocorrem durante o período autoritário getulista, de forma a explicitar as articulações metonímicas que se verificam nas duas obras não apenas entre história e literatura, como também entre forma estética, análise da subjetividade e processo social.
}

PALAVRAS-CHAVE: Literatura brasileira; Literatura e violência; Estudos comparados.

\begin{abstract}
This article aims at studying the representations of State violence presented in Desolação and Passos perdidos, both novels by the Brazilian author Dyonélio Machado. In order to achieve this aim, it is necessary to understand the shaping of political consciousness in the characters, considering the authoritarian Getulio Vargas' government and the metonymical articulations verified in both works not only between history and literature but also involving aesthetical values, analysis of subjectivity and social process.
\end{abstract}

KEYWORDS: Brazilian literature; Literature and violence; Comparative studies. 
Editadas na década de 1940 por José Olympio - responsável, na década anterior, pelo lançamento da maior parte das obras ligadas ao realismo social -, Desolação e Passos perdidos são, respectivamente, a quarta e a quinta obras literárias publicadas pelo escritor e psiquiatra Dyonélio Machado, antecedidas por Um homem pobre (1929), Os ratos (1935) e O louco do Cati (1942), mantendo com este último romance uma relação de continuidade, uma vez que situações e personagens de um reaparecem nos outros.

Nos livros anteriores, a atenção às relações entre forma literária, subjetividade e processo social já ocupava o autor. Mas é em Desolação que, pela primeira vez, tais relações compõem o próprio tecido da ação da narrativa, procedimento recorrente em Passos perdidos, ao representar os caminhos e descaminhos de um operário que se vê envolvido numa trama de repressão policial ligada aos fatos subsequentes às insurreições ocorridas em 1935, que desencadearam um dos episódios mais tenebrosos de violência praticada pelo Estado na história do Brasil.

O objetivo do presente artigo é apresentar um conjunto de reflexões em torno de questões concernentes à representação da violência de Estado na literatura, mediante estudo de caso focado em Desolação e Passos perdidos, de Dyonélio Machado, de forma a tentar entender como se processa, no plano mimético, o entrelaçamento entre ficção e realidade histórica proposto nas duas obras do romancista sul rio-grandense.

\section{O TIRANO DESFILA SOBRE A TERRA DESOLADA}

A obra romanesca de Dyonélio Machado é marcada por um "retesamento que a maioria de seus romances mantêm entre história e elaboração narrativa". Essa característica é intensificada pela trajetória pessoal do escritor sul rio-grandense, na qual se encontram passagens pela política institucional - uma vez que Dyonélio foi deputado - e por prisões políticas durante a segunda metade da década de 1930, o que, sem dúvida, fornece lastro suficiente ao programa estético e ético presente em romances como O louco do Cati, Desolação e Passos perdidos, que se relacionam diretamente com o contexto sociopolítico brasileiro a reboque da Insurreição Comunista de 1935 e da vigência do Estado Novo (1937-1945).

1. PACheco, Ana Paula. "Na boleia de Borboleta”. In: Machado, Dyonélio. Desolação. São Paulo: Planeta do Brasil, 2005, p. 312. 
A Dyonélio Machado interessa, de fato, essa tensão entre o estar na história e o fabular. Daí a importância que a aproximação entre as escritas da história e do universo diegético alcança na plasmagem da própria narrativa. Como sinaliza Antonio Candido em "A literatura e a vida social", há que se atentar para a possibilidade de os dados sociais serem objeto, em diversos graus, de processos de "sublimação"2 pelo texto. Seguindo na terminologia de cariz psicanalítico e expandindo a proposição de Candido, é possível afirmar que os dados sociais podem ser objeto, em diversos graus, de processos de sublimação (Sublimierung) e recalque (Verdrängung) pelo texto, de forma a garantir para o texto literário uma posição tríplice - em que forma estética, subjetividade e processo social se relacionam e se articulam.

A partir desse enquadramento, Desolação afirma sua posição própria como um texto que renuncia tanto ao tom panfletário quanto à opacidade completa em relação aos dados sociais, preferindo articular-se por meio da interseção cerrada entre o destino do protagonista e a própria tessitura histórica. As horas agourentas do regime ditatorial (com o aparato institucional da violência) são vividas não apenas por Maneco Manivela como também por personagens secundárias tais como o dr. Matos ou o dono da hospedaria, que passam a se ver em conflito e em confronto com forças ideológicas reais.

Uma das formas como o autor explora os efeitos desnorteantes sobre a psique implicados na vivência sob um regime ditatorial é a espiral de paranoia que plana sobre a cabeça das personagens e ameaça monopolizar e devorar toda a atividade anímica, à maneira de um vampiro tirânico sempre à espreita para a próxima sucção energética.

Todos ali podem ser pegos a qualquer momento. Desolação abre com um homem não identificado (que depois saberemos tratar-se do dr. Matos, ele próprio vagamente implicado com a resistência ao regime) advertindo ao mecânico Maneco Manivela que um terceiro poderia ser um policial:

- Cuidado! Ele é um provocador!

O homem alto, de roupa encolhida, diz-lhe mais ou menos isso e se dissimula entre os demais viajantes que entram e saem. A essa hora da noite há muito movimento na frente da hospedaria. ${ }^{3}$

2. CANDido, Antonio. Literatura e sociedade. Rio de Janeiro: Ouro sobre Azul, 2011, p. 30.

3. MaChado, Dyonélio. Desolação, cit., p. 5 . 
É tanto alarmante como igualmente suspeita a advertência de Matos, a ponto de ecoar na mente de Manivela, que a associava com fatos comprometedores consigo ocorridos pouco antes:

Manivela fica com os olhos metidos naquele movimento, mas na verdade com o ouvido ouvindo o aviso:

- Tenha cuidado com o seu amigo: ele é um provocador.

"Provocador" é um sujeito que tem ligações com a polícia. Na realidade, um "policial". Um rapaz que viera do Rio e que pretendera instruí-los numa reunião clandestina, realizada para esse fim, falara muito nos provocadores, nos "policiais", nos delatores, nos espiões. Queria precavê-los do perigo que eles ofereciam ao "movimento"... 4

Ao abrir o romance com essa cena e sob a sombra da figura do espião da polícia política, Dyonélio sinaliza, desde logo, a paranoia como estado de consciência dominante ao longo da narrativa. Se todos ali podem ser pegos a qualquer momento, é porque qualquer um pode ser um agente da repressão. Como relatou José Joffily, sobrevivente da Insurreição Comunista de 1935, o momento era convulsivo: "é certo que dali para a frente multiplicaram-se nossas perplexidades, sopitadas, no entanto, pelo clima de temor que se adensava numa época de intrigas e desconfianças generalizadas". ${ }^{5}$ Do temor ao terror - a distância era, efetivamente, menor do que se imaginava. Como ressalta Joffily, o que ocorrera em 1935 "traria um notório cortejo de nefastas sequelas. Desde a violenta repressão contra as liberdades públicas e os direitos individuais até o golpe de 10 de novembro de 1937”, 6 com a implantação da “Terceira República Brasileira', culminando em um 'cenário de sangue e estupidez"' ${ }^{7}$ No entendimento de historiadores das movimentações revolucionárias verificadas em Natal, Recife e no Rio de Janeiro naquele ano, "é frequente também que se considerem os levantes como causa, se não a única, pelo menos a principal, da implantação do Estado Novo no Brasil". Como

4. Id., pp. 5-6.

5. Joffily, José. Harry Berger. Rio de Janeiro: Paz e Terra; Curitiba: UfPR, 1987, p. 50.

6. Id., p. 57 .

7. Id., p. 58.

8. VIAnna, Marly de Almeida Gomes. Revolucionários de 35. Sonho e realidade. São Paulo: Companhia das Letras, 1992, p. 17 . 
escreveria Jorge Amado em Capitães da Areia, aquele foi o ano "em que todas as bocas foram impedidas de falar, no ano que foi todo ele uma noite de terror". ${ }^{9}$

Lançados os personagens no interior de um universo onde todos se autodevoram em estado paranoide - em um jogo de mascaramentos através do qual os que parecem ser na realidade não o são -, assim seguirão não apenas ao longo de Desolação como até as páginas finais de Passos perdidos. A imagem com que o último se encerra, com o bonde seguindo numa noite de chuva e treva pelas ruas de São Paulo rumo a uma mais do que provável detenção por agentes da polícia política, é síntese dessa espiral de terror que se instala a partir de 1935, época em que se desenrolam os fatos narrados em ambos os livros.

No interior do bonde, a prisão de Wilson pode ocorrer a qualquer instante; o veículo parte, noite adentro, rumo a um destino ignoto - o que remete à imagem dos trens chegando a Auschwitz-Birkenau, em fila para o extermínio. O que ela causa em Manivela é nada menos que o desamparo, como o próprio narrador ressalta: "A prisão do companheiro é, para Manivela, o desamparo". ${ }^{10}$ Com a prisão de Wilson, terá que cair na ilegalidade e procurar uma outra rede de apoio, com todas as dificuldades nisso implicadas. A supressão da liberdade é uma experiência devastadora; no entanto, permanecer à solta mas em clandestinidade poderia ter efeito até mais arruinador sobre a psique. No relato de José Joffily - que, muito jovem, desempenhou papel menor na Insurreição de 1935, sendo, ainda assim, feito prisioneiro -, as prisões arbitrárias e o lançamento na ilegalidade acarretaram "o estremecimento emocional vivido por quase todos". as prisões sucessivas a que poderia ser submetido um cidadão), que o gozo da liberdade fosse mais temporário do que o desejado, mesmo aqueles lançados fora dos presídios se confessavam em estado de desolação - vide, mais uma vez, o relato de José Joffily: após seis meses de prisão, "ideologicamente me sentia desolado". ${ }^{12}$

A imagem que se articula à maneira de uma contraparte com a do bonde a rumar para a aniquilação em Passos perdidos encontra-se em Desolação e é uma das passagens em que se justifica o título. Tão forte e sugestiva quanto a imagem do bonde a atravessar

\footnotetext{
9. Amado, Jorge. Capitães da Areia. São Paulo: Companhia das Letras, 2008, p. 270.

10. Machado, Dyonélio. Passos perdidos. 2. ed. São Paulo: Moderna, 1982, p. 179.

11. JOFfily, José. Harry Berger, cit., p. 43.

12. Id., p. 52.
} 
a treva e a chuva, é a imagem da "chapada árida, agora açoitada por aquele duplo látego: o vento e a areia. Desolação". ${ }^{13}$ Há, aqui, outra imagem-síntese do momento histórico: a paisagem política achatada (em sua homogeneidade não há lugar para a diferença) e esterilizada pelos golpes violentos de um duplo látego com que a açoita o Tirano.

Não apenas da paisagem política, a desolação também implica a devastação, a ruína, a desertificação e o despovoamento de si mesmo, atingido, em pessoa (quando não em efígie), pela ação repressiva de um governo no qual se verificava o "prolongamento da política por meio da violência”. ${ }^{14}$ As relações entre as dimensões psicossocial e política se reafirmam no trauma: a desolação não é causa, é sintoma.

\section{O DUPLO LÁTEGO EM AÇÃO}

Manivela é personagem com uma trajetória muito particular, a crer-se na forma como é descrita nos dois romances.

Atente-se, desde logo, para seu codinome. A manivela, além de evocar o jargão automobilístico (com o qual Maneco, como mecânico, está familiarizado), é um dispositivo que se liga, em sua extremidade, a uma engrenagem para a produção de movimento. Parece haver já no nome do personagem a sinalização do modo como Maneco se apresenta no mundo, sua posição na sociedade de classes e o dínamo de suas ações, afinal a manivela, ao entrar em contato com a engrenagem, pode transmitir ou receber movimento, retendo uma potência ambivalente, que parece carregar significados potencialmente alegóricos. A construção ambígua do personagem revela-se um dos elementos mais desenvolvidos em termos de realização estética, aliada à prospecção da subjetividade e à atenção aos dados sociais. É nela - e juntamente com outras situações narrativas muito bem construídas, como as variações no ritmo da narrativa, a disposição temporal dos fatos narrados etc. - que se explicita o valor estético de Desolação e Passos perdidos, sobretudo pelo grau de elaboração romanesca que apresentam, muito além de um simples decalque mimético de fatos históricos, envolvendo, portanto, um trabalho de imbricamento entre forma estética, subjetividade e processo social.

13. MaChado, Dyonélio. Desolação, cit., p. 56.

14. ARENDT, Hannah. Da violência. Brasília: Editora da UnB, 1985, p. 4. 
A posição inicial de Maneco Manivela é regida por uma inclinação ideológica à justiça social (dada, até mesmo, sua condição subalterna na sociedade de classes) que o fazia votar na oposição, pois "não compreendia um movimento político que não tivesse à frente certos nomes. Nem o povo, a gente pobre, a ele se incorporaria. Ela precisa saber-se 'amparada"'.15 Atrai para seu círculo de convívio pessoas com semelhantes inclinações, caso de um amigo chamado Maciel, responsável por levá-lo a uma reunião onde se "atacara muito o imperialismo". ${ }^{16}$

Nessa reunião, em dado momento Maneco é interpelado por um militante, revelando que sua ignorância sobre o que se passa ali não é total, embora tampouco seja possível acreditar que realmente compreendesse as questões postas em jogo: “'Tu sabes o que vem a ser isso?' - perguntara-lhe um dos presentes. 'A luz, parece'. 'Ah! então, menos mal". ${ }^{17}$ Daquela noite restavam-lhe ainda algumas palavras em eco: “imperialismo,' 'contradições,' 'incompreensões,' 'debilidade,' subestimar'...", ${ }^{18}$ farejando vagamente o potencial semântico nelas implicado. Sobre o militante e sua fala, "achava-o um tanto pernóstico, vivendo num mundo irreal, apresentando o operário dum modo irreconhecível para eles próprios, operários"."19

Reconhece ter ido à reunião por um misto de curiosidade e camaradagem com Maciel, mas, no fundo, não lida facilmente com os temas propostos pelo amigo - como, por exemplo, a questão da propaganda política -, e sua experiência esteve marcada, desde o início, por certo temor à repressão policial e por uma obediência cega à lei como entidade coercitiva das condutas humanas:

[...] esse amigo falava-lhe do papel 'político' da propaganda. Político? Se os próprios jornais não incluíam nas seções da Política as notícias sobre o movimento, mas na crônica policial! Sempre se impressionara com isso. Parecia que todos os que tivessem essa estranha política estavam, automaticamente, fora da lei. E é outra coisa que ele também não admite. Pelo menos, consigo. ${ }^{20}$

\footnotetext{
15. Machado, Dyonélio. Desolação, cit., p. 16.

16. Ibid.

17. Ibid.

18. Id., p. 58 .

19. Id., p. 104.

2o. Id., p. 16.
} 
A despeito de sua curiosidade e camaradagem, é como se houvesse, portanto, uma incompatibilidade entre Maneco e os membros do movimento. Em sua posição inicial, chega mesmo a ter "receio de que possa ser confundido com essa gente". ${ }^{21}$ Repugnalhe não apenas a ideia da ilegalidade, como também a da clandestinidade e, no fundo, a hipótese de dissolução da existência individual no âmbito da ação social e coletiva implicada na atuação política: "Não é medo da cadeia ou de qualquer outra coisa, mesmo pior. Mas tem receio dessa vida à parte. Ele nem quereria ser rei, se pudesse! Acha que rei, a família do rei, a sua própria casa não são do indivíduo; pertencem a um outro mundo, impessoal". ${ }^{22}$

Manivela não é um militante, até mesmo porque não atingiu consciência de classe, já que nele os esforços nesse sentido ainda se apresentam de forma vaga e confusa, se não embrionária. Isso não o impede de envolver-se, de forma nem sempre coincidente com sua vontade, com elementos ligados ao movimento. Como se lê em O louco do Cati (do qual Desolação funciona à maneira de um desdobramento), o mecânico Manivela retira da oficina um antigo automóvel (o "Borboleta") e lança-se a uma deriva rumo ao litoral sul rio-grandense em companhia de colegas e dois desconhecidos com os quais travara contato antes - um deles justamente Norberto, que estaria em fuga por conta de algum incidente subversivo envolvendo sua pessoa.

A expedição divide-se, em dado momento, e o suspeito subversivo separa-se da mesma. Livre dessa companhia problemática, Maneco, porém, não demorará a sentir-se novamente em perigo.

À medida que se deslocam pelo interior do Rio Grande do Sul, os tripulantes do Borboleta recebem os ecos dos eventos políticos convulsivos em curso naquele momento. Ao tentarem alcançar um atalho para Palmares, "numa curva da estrada, sobre uma leve subida, depara-se-lhes uma habitação humana. É um rancho pardo, terroso, agreste, sem vida”. ${ }^{23}$ Mesmo ali, no rancho de Ivo, situado no Brasil profundo, já começavam a ecoar as notícias propagadas pela imprensa e pelos viajantes (como Manivela e seus colegas), muitas delas francamente fantasiosas, envoltas numa aura de mistério e temor:

21. Ibid.
22. Ibid.
23. Id., p. 47. 
Seu Ivo esteve na capital ultimamente. Soube que tinha havido prisões.

- Um pessoal que está contra o governo.

Só sabe dizer isso. Não conhece detalhes. Lá pelo pouso das carretas, no Caminho do Meio, falava-se que tinha havido uma revolução. Mas ele não acreditava. Fala-se em tanta coisa...

Tinha havido, sim, esclarece Manivela. Logo sufocada.

- Mas não em Porto Alegre!

- Não: no norte e no Rio.

O que é, porém, estranho nessa de agora é que parece que o pessoal está agindo por instigação ou com a colaboração de gente de fora do país.

- Vocês acreditam? - pergunta Leo; mas fica sem resposta. ${ }^{24}$

Na parada na hospedaria em Palmares, Maneco encontra outro colega suspeito (Bajé), que "distribuía uns manifestos que Manivela leu e onde viu muitas coisas sobre diferenças sociais". ${ }^{25}$ Bajé, que fora preso, agora era apontado como "provocador" pelo dr. Matos, tornando sua conduta duplamente suspeita e comprometedora para Maneco. De todo modo, a fala de Bajé adverte os presentes para o fato de que uma grande onda de repressão se desencadeou no país.

O encontro entre Bajé e Manivela ocorre justamente no dia 18 de dezembro de 1935. Como observa Bajé, "a Constituição devia estar sendo reformada naquele momento" ${ }^{26}$ e, com as alterações aplicadas sobre a Carta Magna de 1934, começaria a pavimentar-se o caminho rumo à deflagração do Estado Novo, ocorrida em 1937. A reforma focalizava artigos que tratavam, por exemplo, da equiparação entre guerra externa e guerrilha civil para efeitos de aplicação do artigo 161, que tratava da decretação do estado de guerra. Esse artigo se conectava de forma direta a outro, 0 175, que dizia respeito à decretação de estado de sítio, prevista tanto para o caso de guerra externa como de insurreição armada interna. Com a própria Carta de 1934, no mencionado artigo 175, ao tratar da vigência do estado de sítio,

eram admitidas as seguintes medidas de exceção: a) desterro para outros pontos do território nacional, ou determinação de permanência em certa localidade; b) detenção em edifício ou local não destinado a réus de crimes comuns; c) censura de correspondência

\footnotetext{
24. Id., p. 50.

25. Id., p. 8 .

26. Id., p. 9.
} 
de qualquer natureza, e das publicações em geral; d) suspensão da liberdade de reunião e de tribuna; e) busca e apreensão em domicílio. ${ }^{27}$

Ainda assim, Vargas desejava ampliar a extensão dos dispositivos estatais de repressão ideológica, com o que chamou, em seu Diário, de "um castigo exemplar". ${ }^{28}$ Ressurge o Tirano - e mais uma vez armado com o duplo látego.

Muito longe de ser um líder revolucionário, o mecânico Maneco não acredita nem na revolta nem no sindicalismo como forma de articulação de transformações sociais: "Manivela é operário e não quer se revoltar: quer ganhar mais". ${ }^{29}$ No entanto, em que pese o distanciamento ideológico (que por vezes se revela incompatibilidade a conviver com certa atração curiosa que, contraditoriamente, o faz tangenciar, ainda que de forma incidental e descomprometida, o movimento), seu destino individual também é sugado para o interior do vórtice de violência e repressão que domina o país.

À medida que avança em sua deriva, Manivela tenta convencer-se de que sua tangência com o movimento insurrecional era mínima, "uma coisa boba"; $3^{\circ 0}$ os esforços são vãos, pois logo começa a perceber que, sob o domínio de um estado de exceção, "quando a polícia o encanasse, desvendasse tudo, pequenos fatos sem importância tomariam vulto: o seu comparecimento à reunião, os manifestos lidos, seus encontros com Bajé, o auxílio (o auxílio!) que dera a Norberto na sua 'fuga"' ${ }^{11}$ Progressivamente tomado pela paranoia, "Manivela espia-se, espia para os lados. Esgazeia o olhar. Tudo repentinamente se lhe apareceu mudado". ${ }^{2}$ Em um estado de exceção, o delírio persecutório deixa de ser delírio para ingressar no campo do possível cotidiano. Os efeitos sobre a psique são devastadores: trêmulo, Maneco pressente que, embora não tenha participado dos levantes, encontra-se, como toda a população do país, sitiado, em estado de pânico, mesmo ele considerando que, ainda assim, "deve-se resguardar de cair no 'desespero", ${ }^{33}$

27. MARques, Raphael Peixoto de Paula. "Estado de exceção e mudança (in)constitucional no Brasil”. Revista História Constitucional. Centro de Estudios Políticos y Constitucionales de Madrid, Universidad de Oviedo, n. 14, pp. 356-7, set. 2013.

28. VArgas, Getúlio. Diário. Volume I (1930-1936). São Paulo: Siciliano; Rio de Janeiro: FGV, 1995, p. 448.

29. MAChado, Dyonélio. Desolação, cit., p. 52.

30. Id., p. 104.

31. Id., p. 105 .

32. Ibid.

33. Id., p. 106. 
que, sem dúvida, seria a próxima parada em seu itinerário. A calma prosaica de seu cotidiano de operário fora "substituída por aquele medo súbito, que o empolgou, como uma emboscada". ${ }^{34}$ Aqui surge a imagem-síntese que justifica o título Passos perdidos. Solto mas prestes a ser preso novamente, já observado por espiões da polícia política (disfarçados de homens comuns, num exemplo flagrante de burocratização da infâmia), Maneco Manivela se lança à multidão durante um horário de intenso tráfego humano, à espera de um encontro talvez mágico, capaz de reverter a iminência do cumprimento de seu destino de prisioneiro político sob um estado de exceção e sob a chuva de São Paulo:

E, entrando na mole que desfila, que passa, repassa; acertando o seu pelos passos que demandam os seus lugares, os seus pontos certos - até experimenta uma sensação de descanso físico, de descanso para os pés, fatigados daquele esperar lento e cauteloso dentro da praça escura, encharcada...

Vai assim até uma das esquinas. Seguiu a calçada mais movimentada. Dá a volta ao fim. Vem vindo por dentro, a passos lentos, perdidos...

Já quase desespera!... ${ }^{35}$

Os incidentes que o levaram à prisão são emblemáticos da situação de terror experimentada pelas mais diversas camadas da sociedade brasileira após 1935. Presenteado pelo dr. Matos com um pequeno volume de doutrinação comunista, Manivela acaba por esconder a comprometedora brochura, juntamente com alguns jornais considerados subversivos, no interior do automóvel (o "Borboleta"), temendo ser flagrado com semelhante conteúdo, a ele transmitido por uma figura policialmente conhecida (o advogado fora preso pouco antes). O automóvel é vendido, mas Manivela receia deixar a brochura ali dentro e ser posteriormente incriminado. Devorado pela paranoia, invade o domicílio do novo proprietário do Borboleta e ateia fogo ao carro, a fim de destruir, completamente, a prova que contra ele poderia ser produzida. É, contudo, flagrado por policiais, concluindo Desolação com essa cena incendiária.

Não nos enganemos em relação a dois pontos da trajetória de Manivela.

O primeiro diz respeito ao fato de o estado de exceção tirar de circulação mesmo figuras menores ou colaterais - ou ainda de envolvimento mínimo ou discutível, caso de

\footnotetext{
34. Id., p. 105.

35. Id. Passos perdidos, cit., p. 155.
} 
Manivela. O que se viu foi, efetivamente, uma avalanche de prisões, com o recrudescimento brutal das forças repressivas, a cargo da polícia política. A paranoia de Manivela não é hiperbólica: ela nasce e se alimenta da constatação de um "clima de temor que se adensava numa época de intrigas e desconfianças generalizadas" ${ }^{36}$

O segundo relaciona-se com o papel desempenhado pela palavra (impressa ou oral) no período. Como ressalta Maria Luíza Tucci Carneiro, "tanto os repressores quanto os revolucionários sempre tiveram consciência da força da palavra, pois era através do discurso oral, escrito ou imagético que as ideias circulavam, seduzindo, reelaborando valores e gerando atitudes" ${ }^{37}$ Portanto, não é hiperbólico o medo que Maneco Manivela tinha de ser flagrado com o comprometedor livro presenteado pelo dr. Matos. Não raramente, era por meio de brochuras com sínteses didáticas como essa que se operava o processo de cooptação de novos militantes. José Joffily reconhece a importância dessas brochuras em sua formação, quando, saído da revolução de 1930, deparou-se com uma delas:

Então, caiu-me nas mãos um livrinho de poucas páginas - $O A B C$ do Comunismo - que teria efeito multiplicador em minha juvenil curiosidade intelectual. Com alguns meses, o marxismo foi se transformando para mim numa lente mágica, através da qual via com clareza todos os fatos passados e presentes, econômicos e metafísicos. Dava-me segurança para compreender, dentro de uma linha abrangente e coerente, a realidade universal, cimentada por um desafio para reagir contra a desigualdade social..$^{38}$

Seria a obra referida por Joffily uma condensação da obra homônima assinada por Nikolai Bukharin e Eugen Preobrazhensky e publicada em 1920? Bukharin seria executado em 1938, na onda da Grande Purga cometida por Stalin desde 1936.

Os arquivos policiais elencam títulos e quantidades de exemplares apreendidos desse tipo de publicação circulante naquele momento histórico. Durante uma visita ao estoque da editora Unitas, os policiais saíram carregados de material considerado subversivo:

36. JOKFILlY, J. Harry Berger, cit., p. 50.

37. CARnEIRo, Maria Luíza Tucci. “Os arquivos da polícia política brasileira: intolerância, repressão e resistência”. In: vianna, Marly de Almeida Gomes et al (Orgs.). Presos políticos e perseguidos estrangeiros na Era Vargas. Rio de Janeiro: Mauad X, 2014, p. 23.

38. JOFILly, J. Op. cit., pp. 39-40. 
A título de ilustração dessa varredura ideológica, selecionamos algumas das obras confiscadas em grandes quantidades: 1451 volumes de Karl Marx, sua vida, sua obra, de Max Beer; 798 volumes de Os problemas do desenvolvimento da URSS, de Leon Trotsky; 956 volumes de O marxismo, de Karl Kautsky, Lenin, Plekhanov, Rosa Luxemburgo; 581 volumes de O que é a Revolução de Outubro, de Trotsky; 810 volumes do Manifesto comunista, de Marx e Engels; 1014 volumes de Poemas proletários, de Paulo Torres; 1060 volumes de O anarquismo, de Piotr Kropotkin; 325 volumes (brochura) de Han Rymer e o amor plural, de Maria Lacerda de Moura, entre centenas e centenas de outros títulos. Em 1938, após ter sido requerida a massa falida da Gráfica Editora Unitas Ltda., o Deops/sp ordenou o confisco de 25.696 livros, sendo remetido ao sr. Juiz [não identificado] um exemplar de cada título. ${ }^{39}$

Na lista referente à Unitas, chama atenção a presença de Poemas proletários, de Paulo Torres. Não se conseguiu localizar um exemplar do livro, mas, pela diligente pesquisa apresentada em uma dissertação na área de História Social da UsP, foi possível resgatar pelo menos um poema integrante do livro, que segue abaixo transcrito, publicado originalmente em O Trabalhador Gráfico, periódico paulista, em dezembro de 1931:

\section{Contradição}

os cereais eram eram tantos

que apodreciam nos armazéns.

as casas da cidade eram tantas que estavam desalugadas.

os sem-trabalho eram tantos

que se atrapalhavam nas ruas pedindo comida.

os sem-trabalho eram tantos

que se empilhavam dormindo

nos bancos dos jardins. ${ }^{40}$

39. Carneiro, Maria Luíza Tucci.“Os arquivos da polícia política brasileira”, cit., p. 26.

40. Apud Castellan, Glaucia Rodrigues. Artesãos da subversão. Os trabalhadores gráficos e o Deops: repressão e resistência durante a Era Vargas (1930-1945). Dissertação apresentada à Faculdade de Filosofia, > 
Ainda entre as obras apreendidas na Unitas, encontra-se Han Rymer e o amor plural, da pensadora anarquista brasileira Maria Lacerda de Moura, uma das fundadoras da Liga para a Emancipação Intelectual da Mulher, em 1920.

Na Bahia, em 1937, são queimados exemplares de obras de Jorge Amado e José Lins do Rego, "apreendidos nas Livrarias Editora Bahiana, Catilina e Souza", ${ }^{41}$ sob acusação de propagarem o credo comunista. Não se restringiu, contudo, apenas à Bahia a repressão editorial, sendo certo que, logo depois, ocorria semelhante apreensão no Rio de Janeiro, alvejando novamente a obra de Jorge Amado, em cuja companhia figuravam ainda Luís Martins (com seu Lapa) e até mesmo uma tradução de Tarzan, o invencível "este último havia sido condenado por empregar - entre tantos outros diálogos comuns aos personagens das histórias em quadrinhos daquele período - a expressão 'camarada', considerada representativa do vocabulário dos partidários do comunismo". ${ }^{42}$

Portanto, em defesa dos temores de Maneco Manivela, serve de prova a perseguição desfechada pelos agentes estatais da polícia política no âmbito editorial, que conduziu a fechamentos, processos judiciais, apreensões e incinerações de exemplares de livros publicados não apenas por editoras como a Pax, a Marenglen e a Unitas (que trabalhavam com obras marxistas e autores russos), pois brochuras didáticas e livros técnicos não eram alvo único da ação policial, estendida contra obras literárias como Capitães da Areia ou os Poemas proletários.

A prisão de Maneco fora ilegal, e não menos ilegal sua libertação: "sim: foi libertado, ao cabo de quase dois anos, por não haver sido denunciado. Esteve 'esquecido', como tantos outros". ${ }^{43} \mathrm{O}$ fato de andar pelas ruas de São Paulo (para onde se dirige após a estadia no presídio do Rio de Janeiro) não confere a Manivela segurança sobre sua liberdade, pois sabe que pode ser preso a qualquer momento. Se há algum espanto no fato, é por ele ser tão francamente ilícito: “e aquela prisão não está ligada ao seu processo: o caso é outro... São essas reprisões, com que a reação se penitencia da liberalidade daquelas libertações em massa"."44

> Letras e Ciências Humanas da Universidade de São Paulo, 2010. Orientada pela Profa. Dra. Maria Luiza Tucci Carneiro.

41. CArneiro, Maria Luíza Tucci. “Os arquivos da polícia política brasileira”, cit., p. 22.

42. Ibid.

43. MaChado, Dyonélio. Passos perdidos, cit., p. 8.

44. Id., p. 174. 
Correndo o risco de ser capturado novamente, Maneco Manivela não tem tempo para deixar florescer em si a perplexidade, uma vez que é imediatamente conclamado a manter o estado paranoide e a permanente vigilância:

Agora reflete: por que o haviam de prender outra vez? A informação que tivera é que estavam reprendendo militares, jornalistas, um ou outro comunista de mais evidência, $\mathrm{e}$ que haviam, como ele, sido libertados meio que de improviso. Mas, também, por que é que o tinham retido tanto tempo na prisão, sem processo?

- Você foi esquecido - afiançava o pessoal.

Não era bom ter sido esquecido. Nem podia, ainda na véspera da sua libertação, prever quanto tempo ainda haveria de gramar ali, até que se lembrassem do seu caso. Mas, desde uma vez que o soltaram, muito melhor esquecido. - Decerto vão esquecê-lo também agora, que está na rua... ${ }^{45}$

A possibilidade ambígua e aterrorizante de ser esquecido pelo sistema jurídico no âmbito penitenciário, as prisões arbitrárias e as “reprisões" duplamente arbitrárias, a dádiva agridoce das libertações em massa de presos que nunca deveriam ter sido encarcerados, tudo isso se sobrepõe na psique de Manivela de forma traumática e ontologicamente devastadora, ao mesmo tempo que marca no destino da própria personagem os efeitos da realidade histórica. Como escreveria Dyonélio, num capítulo dedicado às reflexões sobre a violência de Memórias de um homem pobre (momento máximo de sua escrita íntima), o que havia era "a violência cínica e triunfante". ${ }^{6}$ Surge, novamente, o Tirano com o duplo látego, sempre apto a acachapar e a esterilizar os movimentos tentados pelo outro: "o governo ditatorial vibra um golpe total: nos adversários, que encarcera, tortura, mata; nos correligionários e auxiliares, que avilta com a perda da própria personalidade". ${ }^{47}$

\footnotetext{
45. Id., p. 10.

46. machado, Dyonélio. O cheiro de coisa viva. Rio de Janeiro: Graphia Editorial, 1995, p. 124.

47. Id., p. 124 .
} 


\section{ESCRITA COMO SUPERPOSIÇÃO DA DIFERENÇA}

O que desconcerta as personagens e o leitor em relação à espiral de terror que asfixia e paralisa em Desolação e Passos perdidos é o fato de a mesma ter por agente o Estado. Onipresente, ele pode imiscuir-se em quaisquer condutas, até mesmo naquelas para as quais não lhe cabe ingerência (como as condutas internas, por exemplo). Não à toa um colega de prisão adverte Manivela nos seguintes termos, que ecoariam muito depois de proferidos na cela: "Não tem perigo de se livrar deles...". $4^{8}$

Já sabemos que a paranoia de Maneco não é infundada. Como frisa José Murilo de Carvalho, a violência promovida pelo próprio Estado não foi rara ao longo da ditadura de Vargas, tendo se verificado um recrudescimento barbárico das forças repressivas a partir da Insurreição Comunista de 1935:

Os acusados eram processados e julgados pelo Tribunal de Segurança Nacional, criado logo depois do levante comunista de 1935, ainda antes do Estado Novo. Após a revolta integralista de 1938, já no regime de exceção, o regulamento do Tribunal foi alterado para apressar os julgamentos e reduzi-los quase a rito sumário, ou seja, sem processo formal. Recebido o inquérito, o juiz dava imediatamente vista ao procurador e citava o réu. $\mathrm{O}$ procurador tinha 24 horas para a denúncia. Findo o prazo, era marcada audiência para instrução e julgamento dentro de 24 horas, tempo que tinha também a defesa para se preparar. Em cinco dias, tudo se resolvia. Recurso só era admitido para o próprio Tribunal pleno, cuja sentença era irrecorrível. O Tribunal processou mais de 10 mil pessoas e condenou $4099 .^{49}$

É importante destacar que a prática de violência de Estado envolvendo Vargas foi denunciada de forma aberta pela grande imprensa pelo menos desde a série "Falta alguém em Nuremberg", assinada por David Nassser e publicada inicialmente em 1946 na revista $O$ Cruzeiro, depois reunida em livro homônimo, no ano seguinte. A anistia concedida pelo próprio Vargas em 1945 dificultou a apuração das violações praticadas pelo Estado durante os anos em que esteve no poder. Algumas tentativas de investigação

\footnotetext{
48. Id. Passos perdidos, cit., p. 177.

49. CARvalho, José Murilo de. "Chumbo grosso: assassinato e tortura eram práticas comuns durante a ditadura de Getúlio Vargas”. Revista de História. Rio de Janeiro, Biblioteca Nacional. Edição 59, ago. 2010. Disponível em: http://www.revistadehistoria.com.br/secao/capa/chumbo-grosso. Acesso em: 13 nov. 2015.
} 
conduzidas ao longo da década de 1940 foram engavetadas e mesmo a "Comissão de Inquérito sobre os atos delituosos da ditadura” - presidida por Plínio Barreto e que conseguira reunir os depoimentos de Luís Carlos Prestes, Nasser e Marighela, entre outros - acabou por não produzir resultados políticos tampouco jurídicos contra Vargas, que na década seguinte retornaria ao poder, pelo voto direto.

A atrocidade da violência de Estado atingiu talvez seu ponto de culminância nos casos de Olga Prestes, Harry Berger (cujo padecimento de brutais torturas foi devidamente denunciado pelo jurista Sobral Pinto, que, diga-se, não possuía qualquer afinidade ideológica com o acusado) e Elisa Saborowsky (esposa de Berger, deportada juntamente com Olga, rumo inicialmente a um centro de detenção para prisioneiros políticos e depois aos campos de concentração de Lichtenburg e Ravensbrück, onde faleceu). Se nos porões da Polícia Política a tortura certamente correu solta e as violações aos direitos foram recorrentes, atingindo os mais terríveis graus de crueldade, a paranoia era o estado de consciência dominante.

Como frisa Maria Luíza Carneiro Tucci, "por trás da ação da Polícia Política emerge a figura soberana do Estado (meio real, meio mítica), que, nos momentos de instabilidade política, teve necessidade de nomear seus inimigos", ${ }^{\circ}$ fossem eles da orientação ideológica que tivessem.

Emerge, portanto, à maneira dos filmes expressionistas da Alemanha na década de 1920, a figura do Tirano - aqui sintetizada pelo Poder Executivo de uma República havia pouco tempo proclamada (quando Getúlio toma o poder em 1930, havia menos de cinquenta anos que Deodoro o fizera), mas onde golpes e contragolpes se sucediam em ritmos sismográficos.

Esse Tirano é uma figura paterna e monstruosa, com todos os efeitos destruidores que a mitologia e a psicanálise nele apontam, já que se apresenta como figura onipresente nas narrativas psicanalíticas, e no universo mitológico não raramente se faz necessário seu assassinato para o cumprimento da moira, destino individual curvado diante de forças mais poderosas que a do herói. Ironicamente, Vargas seria chamado de "Pai dos pobres", clichê explorado à exaustão pelo Departamento de Imprensa e Propaganda do regime ditatorial. Assim, como se a História também fosse dotada de um inconsciente, desliza-se, em narrativas como Desolação e Passos perdidos, não apenas o clima paranoico de terror instaurado pelo Estado, como também essa presença do

50. CARneiro, Maria Luíza Tucci.“Os arquivos da polícia política brasileira”, cit., p. 15. 
Tirano, figura paterna que se deve assassinar para que se realize a criação de uma nova imago substitutiva, capaz de gerar as transformações ansiadas. Aqui, porém, a luta do filho para se libertar do Vaterkomplex é fadada ao fracasso, como no sonho de Maneco Manivela, onde reaparece a figura de seu pai, morto, à frente da multidão.

Nesse quadrante, Desolação e Passos perdidos são obras da década de 1940 que procuram sondar o terreno viscoso sobre o qual se realizava a vida política no Brasil da segunda metade da década anterior. A ideia de trabalhar na literatura os processos históricos não apenas como pano de fundo já fora cogitada anteriormente por Jorge Amado, em Capitães da Areia (1937). No final do romance, Pedro Bala - ex-líder dos Capitães da Areia - ouve a voz da revolução e ingressa numa organização clandestina, sendo procurado pela polícia de cinco estados por suas atividades subversivas. No entanto, a atuação de Pedro Bala como agente revolucionário é sumariamente traçada, apenas no final do livro, à maneira de um apêndice, sem incorporar-se organicamente à narrativa. Não é apresentado ao leitor, por exemplo, o processo de transformação do anti-herói Pedro Bala/Capitão da Areia no herói Pedro Bala/líder revolucionário, finalmente imbuído de aspiração e de atributos morais conformes a esse último tipo de personagem.

Isso não ocorre com Desolação ou mesmo Passos perdidos. Em ambos, o destino individual das personagens está diretamente ligado aos processos históricos, de forma a não poder ser sumariamente desenhado, sob pena de enfraquecimento do próprio enredo e da coerência existencial das personagens. É como se Dyonélio alertasse que, dentro ou fora do espaço diegético, não se entra ou se sai do político, pois ele está, desde sempre, presente. Esse grau de imbricação entre destino individual e destino histórico só se verificaria na obra de Jorge Amado na trilogia Os subterrâneos da liberdade, escrita na década de 1950, quando o escritor retorna a narrativa à segunda metade dos anos 30, a fim de apresentar um painel do Estado Novo e da luta pela democracia e contra a violação de liberdades individuais durante a Era Vargas. Nesse ponto, há que se ressaltar, mais uma vez, a já mencionada qualidade de fabulação que também distingue romances como Desolação e Passos perdidos e faz com que tais obras não se reduzam a decalques miméticos da realidade histórica.

Também não se verifica em Desolação a presença de um tom panfletário ou mesmo didático - que atravessa Capitães da Areia e também Passos perdidos. Pelo contrário: o Maneco Manivela que é representado em Desolação (anterior à experiência na prisão) constitui-se uma voz mergulhada em estado de alienação, cujos posicionamentos e condutas nem sempre são condizentes com os protocolos que regem o modus operandi de um militante - de que ele, sinceramente, sabe estar bem distante, ainda que 
sua posição como simpatizante lhe cause transtornos, dada a vigência de um estado de exceção. É verdade que, em Passos perdidos, como já afirmado acima, essa característica se apaga, em prol de encenações didáticas que versam sobre questões como ideologia e sexualidade, liberdade e responsabilidade etc. Porém, em Desolação a voz de Maneco permanece imune ao diapasão panfletário e o que se comunica é, antes, a desagregação de sua psique por uma trama paranoica de perseguição policial de fundo político.

É justamente essa capacidade de condensar no texto literário pesquisa estética, auscultação da subjetividade e atenção aos processos sociais que caracteriza Desolação e Passos perdidos.

Os dados exteriores não transparecem na cena como mero pano de fundo, à maneira de uma cenografia mecanicamente desdobrável e cambiável. Além de serem integrados diretamente à ação da narrativa (coordenando e vetorizando escolhas e atuando sobre o eixo sequencial da mesma), os dados exteriores amalgamam-se ao próprio destino da personagem, ligando-se diretamente a seus atos e suas condutas. Vale ressaltar que Maneco Manivela não é um líder revolucionário, mas, antes, um homem cuja rotina e cuja conduta eram regidas pela normalidade em seu sentido mais estrito, o que não impediu que seu destino individual fosse justaposto ao destino histórico da sociedade em que se encontrava inserido.

Os efeitos dos dados exteriores sobre a psique das personagens são notáveis, colaborando para a criação de uma espiral de repressão e paranoia, sugando para seu interior toda a potência produtiva da subjetividade que poderia ser cooptada para a ação revolucionária direta. O estado de terror é uma estratégia de esterilização da força transformativa emergente e constituía-se, sem dúvida, em um dos látegos com que o Tirano manobrava seus cidadãos-tornados-súditos, no trabalho de devastação da paisagem política.

Não deixa de ser desconcertante notar como Desolação - e não as Memórias de um pobre homem - talvez seja o texto no qual Dyonélio se dispõe a conformar em escrita parte de seu conhecimento empírico sobre os processos psicossociais e políticos em trânsito ao longo daquele momento histórico. Não será nas Memórias (que ficaram até incompletas), e, sim, em Desolação, que se realizará o projeto de Dyonélio de entabular "uma conversa com o passado". ${ }^{51}$ Atente-se que não se está a afirmar que haja uma projeção mecânica do autor sobre o protagonista, afinal Dyonélio foi preso sob acusação de

51. MACHADo, Dyonélio. O cheiro de coisa viva, cit., p. 110. 
delito de opinião antes da Insurreição Comunista, por conta de sua posição como presidente do diretório estadual da Ação Nacional Libertadora, e na sequência aos levantes voltaria a ser encarcerado, embora sem qualquer relação direta com os mesmos. É certo que passagens como as abaixo transcritas podem gerar confusão, sobretudo quando se ressalta que a primeira é extraída de uma entrevista concedida em 1980 e a segunda do romance Passos perdidos (publicado em 1946):

Muita gente me pergunta o que foi pior nesses anos de cadeia. Fui levado para o Rio, no porão de um grande navio, em pleno inverno, numa travessia que durou dez dias. Perdi doze quilos, todos os dentes e algumas unhas. Nada disso, porém, me modificou. ${ }^{52}$

- Olha aí, Maneco - diz-lhe Leo, com um olhar de espanto. "Como caiu a tua barba!...” Ele leva a mão ao rosto, tateando, sem compreender:

- Onde?...

- Aí no lado do queixo!...

Efetivamente seus dedos encontram um rombo liso em meio à sua barba forte... Fora uma queda de cabelo em massa, de repente. Haviam-lhe dito que era uma espécie de tinha - uma tinha nervosa...

Na prisão, por mais de uma vez, lhe aconteceu coisa semelhante. Ficara talvez achacado. ${ }^{53}$

De qualquer forma, como até certo ponto ocorrerá também com o operário Maneco Manivela em Passos perdidos, foi na prisão que o psiquiatra e escritor Dyonélio Machado "conheceu e conviveu com outros socialistas e aderiu ao Partido Comunista,", pelo qual, em 1947, se elegeu deputado estadual constituinte, sem conseguir, no entanto, concluir o mandato, pois "no mesmo ano o partido foi posto na ilegalidade pelo presidente da República e cassados seus parlamentares".55

Obviamente, Maneco não vai tão longe, mas também tem suas conquistas: depois da prisão e do contato direto com militantes, consegue identificar sua posição em relação

\footnotetext{
52. Id., p. 18.

53. MaChado, Dyonélio. Passos perdidos, cit., p. 48.

54. Grawunder, Maria Zenilda. "Sob o signo da solidão: Dyonélio Machado, autobiográfico”. In: MACHADo, Dyonélio. O cheiro de coisa viva, cit., p. xx.

55. Id., p. xxvi.
} 
ao movimento - definindo-se como um simpatizante - e compreende que a vida não se resume a ganhar mais, como pensava em Desolação: agora, "sua questão não é apenas ter o que comer: é o trabalho, o entusiasmo pelo trabalho...." ${ }^{66}$ Obterá, também, insights importantes sobre a sexualidade, que começa a perceber como sendo mais que uma questão de satisfação fisiológica, entendendo os mecanismos econômicos reificadores que se estruturam por trás de práticas sociais como a prostituição. Como prova de que a experiência no cárcere deflagrou, no plano mais imediato, uma alteração no modo de estar no mundo e de para ele olhar, Maneco chega a admitir que "está notando agora que se deixa levar por essa mania de tudo explicar pelo fator social". ${ }^{57}$ É claro que isso não se processa de forma pacífica no operário, pois o mesmo oferece resistência: "Não quero pegar mania nenhuma. Viu gente na prisão sectária à beça, tudo explicando segundo um sistema, todas as formas do pensamento e da ação reduzindo a um método"..$^{8} \mathrm{De}$ qualquer forma, o mesmo Maneco que ingressa no presídio ignorante dos protocolos e dos códigos implicados no movimento (a ponto de saudar com a mão aberta os companheiros de cárcere em sua entrada, sendo advertido por um deles para que fechasse o punho) manifestará seu desejo de aprender russo, incorporará em sua fala alguns termos-chave do jargão ("fator social", "leis capitalistas", "amor livre") e colocará mesmo seu destino nas mãos das "ligações" (contatos políticos) proporcionadas durante a prisão. Sua paranoia também passa a ter justificativa, pois o caso do incêndio do automóvel gerara um processo judiciário, do qual recebeu uma intimação quando em São Paulo, confirmando-se, desse modo, a suspeita de que seu paradeiro fosse conhecido. Sob a ameaça de ser preso novamente, "a liberdade lhe aparece como uma coisa prestes a quebrar, uma coisa frágil...."59

Para além das projeções biográficas, é plausível, portanto, a hipótese de que o conhecimento empírico dos processos históricos em curso (mesmo em sua dimensão traumática e desestabilizadora da trajetória individual) tenha sido trazido à baila como material de construção em sua obra ficcional - o que é corroborado pelo entendimento de Maria Zenilda Grawunder, quando esta afirma o que segue a respeito dos quatro livros nos quais a experiência histórica é chamada para a elaboração de um universo ficcional:

\footnotetext{
56. MAChado, Dyonélio. Passos perdidos, cit., p. 23.

57. Id., p. 13.

58. Id., p. 20.

59. Id., p. 127.
} 
Criados sobre as lembranças sombrias do Cati e das vivências pessoais do cárcere, a narrativa dos dramas do louco e do mecânico Maneco Manivela, em O louco do Cati, Desolação, Passos perdidos e Nuanças, constrói uma espécie de rito de passagem humana, de um estado de consciência simples, quase mítica, para o de conscientização do homem como ser social, vivendo situações-limite de opressão e perseguição. ${ }^{60}$

Em se revelando verdadeira essa hipótese, é importante ressaltar o fato de Dyonélio Machado ter escolhido a prosa de ficção como gênero de suporte. Nesse gesto transparece a consciência de que a escrita da história - sobretudo quando ela diz respeito a eventos traumáticos - está, desde o princípio, implicada com o próprio ato de entendimento e de enunciação dos fatos geradores e seus efeitos, sendo, portanto, impossível qualquer neutralidade discursiva em relação a isso. Se a história é o antípoda da literatura (portanto, um outro longínquo, cuja relação é marcada justamente por uma espécie de 'excesso de diferença'), o encontro que entre elas se estabelece a partir da experiência do trauma vivido em âmbito social se configura, ele mesmo, como um fenômeno de alteridade no qual o Estado prescinde do outro. É assim que a literatura, nesse instante sobrepondo-se ao discurso historiográfico, mantém-se como meio de grande eficácia na obtenção desse registro da dimensão afetiva implicada na experiência do outro. A violência de Estado, ao apagar a diferença mediante dispositivos de homogeneização ideológica, soterra a alteridade e transforma-a em letra morta, em uma supressão da qual a literatura poderia ser uma crônica. É assim que, entre aletheia e pseudos, o texto ficcional se reafirma como processo eficiente de imbricamento entre forma estética, subjetividade e processo social, numa superposição de conteúdos e perspectivas literárias, psicológicas e históricas, que é a marca registrada de Desolação e Passos perdidos.

Marcus Rogério Salgado é Professor Adjunto de Literatura Brasileira na Universidade Federal do Rio de Janeiro (UFRJ)

60. GRAWUnder, Maria Zenilda. "Sob o signo da solidão: Dyonélio Machado, autobiográfico", cit., p. xxii. 